\title{
Bromo-Cyclobutenaminones as New Covalent UDP-N-Acetylglucosamine Enolpyruvyl Transferase (MurA) Inhibitors
}

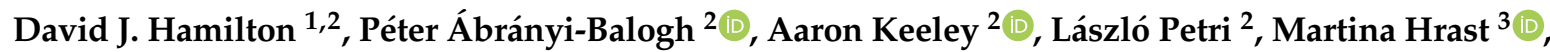 \\ Tímea Imre ${ }^{4}$, Maikel Wijtmans ${ }^{1}$, Stanislav Gobec ${ }^{3}$, Iwan J. P. de Esch ${ }^{1}$ and \\ György Miklós Keserú ${ }^{2, *}$ \\ 1 Division of Medicinal Chemistry, Amsterdam Institute of Molecular and Life Sciences (AIMMS), \\ Faculty of Science, Vrije Universiteit Amsterdam, De Boelelaan 1108, 1081 HZ Amsterdam, The Netherlands; \\ d.j.hamilton@vu.nl (D.J.H.); m.wijtmans@vu.nl (M.W.); i.de.esch@vu.nl (I.J.P.d.E.) \\ 2 Medicinal Chemistry Research Group, Research Centre for Natural Sciences, Magyar tudósok krt 2, \\ H-1117 Budapest, Hungary; abranyi-balogh.peter@ttk.hu (P.Á.-B.); aaron.keeley@ttk.hu (A.K.); \\ petri.laszlo@ttk.hu (L.P.) \\ 3 Faculty of Pharmacy, University of Ljubljana, Aškerčeva 7, SI-1000 Ljubljana, Slovenia; \\ martina.hrast@ffa.uni-lj.si (M.H.); Stanislav.Gobec@ffa.uni-lj.si (S.G.) \\ 4 MS Metabolomics Research Group, Research Centre for Natural Sciences, Magyar tudósok krt 2, \\ H-1117 Budapest, Hungary; imre.timea@ttk.hu \\ * Correspondence: keseru.gyorgy@ttk.hu; Tel.: +36-1-382-6821
}

Received: 8 October 2020; Accepted: 30 October 2020; Published: 3 November 2020

\begin{abstract}
Drug discovery programs against the antibacterial target UDP- $N$-acetylglucosamine enolpyruvyl transferase (MurA) have already resulted in covalent inhibitors having small threeand five-membered heterocyclic rings. In the current study, the reactivity of four-membered rings was carefully modulated to obtain a novel family of covalent MurA inhibitors. Screening a small library of cyclobutenone derivatives led to the identification of bromo-cyclobutenaminones as new electrophilic warheads. The electrophilic reactivity and cysteine specificity have been determined in a glutathione (GSH) and an oligopeptide assay, respectively. Investigating the structure-activity relationship for MurA suggests a crucial role for the bromine atom in the ligand. In addition, MS/MS experiments have proven the covalent labelling of MurA at Cys115 and the observed loss of the bromine atom suggests a net nucleophilic substitution as the covalent reaction. This new set of compounds might be considered as a viable chemical starting point for the discovery of new MurA inhibitors.
\end{abstract}

Keywords: covalent inhibitor; MurA; cyclobutenaminone; antibacterial; irreversible

\section{Introduction}

MurA (UDP-N-acetylglucosamine enolpyruvyl transferase) is a key enzyme in the peptidoglycan biosynthesis that catalyzes the transfer of phosphoenolpyruvate (PEP) to UDP-N-acetylglucosamine (UNAG) [1]. Targeting the catalytic site of MurA leads to the inactivation of the enzyme that increases the osmotic vulnerability of bacteria [2]. MurA is a preferred antibacterial target, as there is no human orthologue for the enzyme. Known MurA inhibitors contain a three- $(\mathbf{1}, 3)$, five-(2,4-9) or occasionally six-membered (10) heterocycle equipped with a halogen atom leaving group $(6,10)$, or an epoxide ring $(\mathbf{1}, 3)$ that are prone to nucleophilic substitution. Other inhibitors contain a double bond $(2,4,5,7-9)$ that is available for Michael addition (Figure 1) [3-6].

Our attention was drawn to the cyclobutenone scaffold, as it also harbors a ring with electrophilic character. Cyclobutenones have received relatively little attention in the literature [7-12], and cyclobutyl 
compounds, in general, are underrepresented in most (fragment) screening libraries [13]. The ring strain of the cyclobutenone unit suggests a substantial reactivity as an electrophile [10,12,14]. Given the foreseen use as covalent fragments, the reactivity and stability in biological assays need to be balanced. Therefore, the electrophilic reactivity was carefully modulated by incorporating an amine functionality in the electrophilic core, giving cyclobutenaminones. As an additional advantage, appending the amine group to the core provides further chemical handles for growing any hit fragments. Last, cyclobutenaminones contain a double bond enabling the incorporation of, e.g., halogen atoms, that can target nucleophilic amino acid side chains, especially that of cysteines.

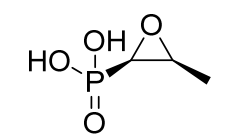

fosfomycin 1 $\mathrm{IC}_{50}($ E. coli $)=8.8 \mu \mathrm{M}$

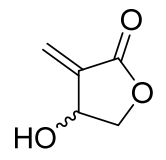

( \pm )-tulipaline B 2<smiles></smiles>

terreic acid 3

$\mathrm{IC}_{50}(\mathrm{E} . \mathrm{col} / \mathrm{i})=2.2 \mu \mathrm{M}$

$\mathrm{IC}_{50}($ E. cloacae $)=14 \mu \mathrm{M}$<smiles>O=c1ssc(Cl)c1-c1ccccc1</smiles>

RWJ-3891 6

$\mathrm{IC}_{50}($ E. coli $)=0.2 \mu \mathrm{M}$

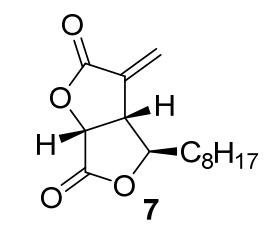

$\mathrm{IC}_{50}($ E. coll $)=0.9 \mu \mathrm{M}$<smiles>O=[N+]([O-])/C(Br)=C/c1ccc(Br)o1</smiles>

4

$\mathrm{IC}_{50}($ E. coli $)=2.8 \mu \mathrm{M}$<smiles>O=C1OC(=Cc2cccc3ccccc23)C(O)=C1c1ccc(C(F)(F)F)cc1</smiles><smiles>Ic1cncnc1</smiles>

9 10

$I C_{50}($ E. coli $)=66 \mu \mathrm{M} \quad I C_{50}($ E. coll $)=3.8 \mu \mathrm{M}$

Figure 1. Known MurA inhibitors with small heterocyclic scaffolds.

In continuation of our interests in finding new MurA inhibitors and in the use of the cyclobutyl motif in drug discovery [6,15-17], here we describe cyclobutenaminone derivatives with carefully-modulated electrophilic character as new warheads for covalently targeting the Cys115 residue in the active site of MurA.

\section{Results and Discussion}

The synthesis of a small set of cyclobutenaminones was accomplished using a strategy based on that from Brand et al. (Scheme 1) [18]. The sequence began with ethoxyacetylene (11), which underwent a [2+2] cycloaddition [18-21] with the in situ generated ketene formed via the base-mediated $\mathrm{HCl}$ elimination from isobutyryl chloride. The two methyl groups were incorporated so as to restrict the nucleophilic character of enaminones (14a-e) to but one position in, e.g., the electrophilic bromination. The sequence furnished ethoxyenone (12) in moderate yield, which was transformed by acidic hydrolysis to 2,2-dimethylcyclobutane-1,3-dione (13) in high yield [18-21]. Next, dione 13 was condensed with various amines in the presence of $\mathrm{AcOH}$ as catalyst at $65^{\circ} \mathrm{C}$ to generate the desired enaminones (14a-e) in moderate yields [18,22]. Bromination of all enaminones was achieved via electrophilic substitution using $\mathrm{Br}_{2}$ and base at $0{ }^{\circ} \mathrm{C}$ to produce bromoenaminones 15a-e $[18,22]$. Selected compounds were subjected to $N$-acylation via deprotonation of the secondary enaminone in tetrahydrofurane (THF) at $-78{ }^{\circ} \mathrm{C}$ by sodium bis(trimethylsilyl)amide (NaHDMS), followed by subsequent trapping by the relevant acid chloride. Conceivably, the acylation of 14a to 16a could also take place at the nucleophilic vinylic position. However, the correct regiochemistry was proven by 2D NMR experiments. The acylations resulted in the corresponding $N$-acyl-cyclobutenaminones (16a and $\mathbf{1 7} \mathbf{a}-\mathbf{b})$ in good yields. 


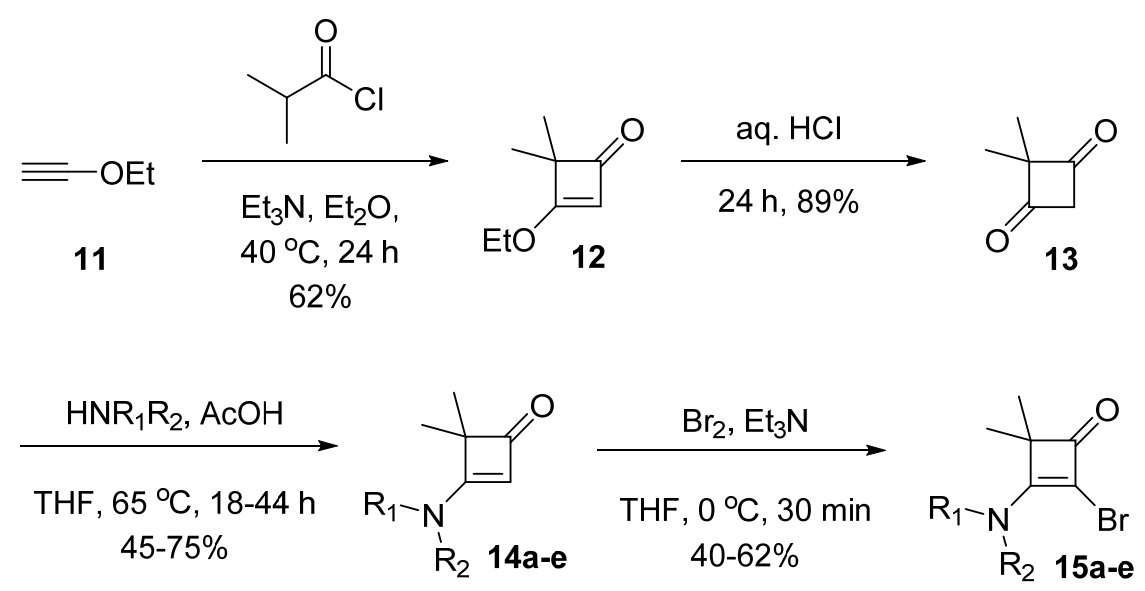

1) NaHMDS, THF, $-78^{\circ} \mathrm{C}, 90 \mathrm{~min}$

2) $\mathrm{R}_{3} \mathrm{COCl}, \mathrm{THF},-78^{\circ} \mathrm{C}, 2 \mathrm{~h}$ $70-80 \%$<smiles>[R3]C(=O)N([R7])C1=CC(=O)C1(C)C</smiles><smiles>[R3]C(=O)N([R7])C1=C(Br)C(=O)C1(C)C</smiles>

Scheme 1. General synthesis route to various (bromo)enaminones and subsequent $N$-acylation of secondary enaminones. Table 1 shows the different substituents introduced $\left(R_{1}, R_{2}\right)$, while $R_{3}=$ Me or $P h$.

Table 1. Structures and biological activity of synthesized compounds.<smiles>[X]C1=C(N([R])[R2])C(C)(C)C1=O</smiles>

\begin{tabular}{|c|c|c|c|c|}
\hline Compound & $\mathbf{R}_{\mathbf{1}}$ & $\mathbf{R}_{2}$ & $x$ & $\begin{array}{c}\mathrm{RA}^{\mathrm{a}}[\%] \text { at } 500 \mu \mathrm{M} \\
\text { and } \mathrm{IC}_{50}[\mu \mathrm{M}]\end{array}$ \\
\hline $14 a$ & $\mathrm{Me}$ & $\mathrm{H}$ & $\mathrm{H}$ & $93 \pm 4$ \\
\hline $14 b$ & $\mathrm{Me}$ & $\mathrm{Me}$ & $\mathrm{H}$ & $99 \pm 1$ \\
\hline $14 \mathrm{c}$ & Et & Et & $\mathrm{H}$ & $96 \pm 2$ \\
\hline $14 d$ & $\mathrm{Me}$ & $\mathrm{PMB}^{\mathrm{b}}$ & $\mathrm{H}$ & $99 \pm 3$ \\
\hline $14 \mathrm{e}$ & $\mathrm{Me}$ & $\mathrm{F}_{3} \mathrm{CCH}_{2}$ & $\mathrm{H}$ & $98 \pm 7$ \\
\hline $16 a$ & $\mathrm{Me}$ & $\mathrm{PhCO}$ & $\mathrm{H}$ & $99 \pm 8$ \\
\hline 12 & - & - & - & $98 \pm 2$ \\
\hline $15 a$ & $\mathrm{Me}$ & $\mathrm{H}$ & $\mathrm{Br}$ & $100 \pm 7$ \\
\hline $15 b$ & $\mathrm{Me}$ & $\mathrm{Me}$ & $\mathrm{Br}$ & $91 \pm 5$ \\
\hline $15 c$ & Et & Et & $\mathrm{Br}$ & $88 \pm 6$ \\
\hline $15 d$ & $\mathrm{Me}$ & $\mathrm{PMB}^{\mathrm{b}}$ & $\mathrm{Br}$ & $13 \pm 1, \mathrm{IC}_{50}=363 \pm 11$ \\
\hline $15 e$ & $\mathrm{Me}$ & $\mathrm{F}_{3} \mathrm{CCH}_{2}$ & $\mathrm{Br}$ & $84 \pm 4$ \\
\hline $17 a$ & $\mathrm{Me}$ & $\mathrm{PhCO}$ & $\mathrm{Br}$ & $12 \pm 3, \mathrm{IC}_{50}=138 \pm 9$ \\
\hline $17 b$ & $\mathrm{Me}$ & $\mathrm{MeCO}$ & $\mathrm{Br}$ & $8 \pm 2, I_{50}=128 \pm 10$ \\
\hline fosfomycin & - & - & - & $8.8[3]$ \\
\hline
\end{tabular}

a $\mathrm{RA} \%$ refers to the remaining activity in the MurA (E. coli) biochemical assay with a fragment concentration of $500 \mu \mathrm{M}$ with $30 \mathrm{~min}$ preincubation at $37^{\circ} \mathrm{C}$; ${ }^{\mathrm{b}} \mathrm{PMB}$ : 4-methoxy-benzyl. 
A library of thirteen fragments was prepared, containing nonbrominated (six) and brominated (seven) cyclobutenaminones, all of which are novel to the best of our knowledge (Table 1). This library was then screened against MurA from E. coli in order to identify possible starting points for the future development of covalent MurA inhibitors. The screening showed that the cyclobutenaminones with a vinylic proton (14a-d) do not give any substantial inhibition. Indeed, the amine substituent selected for balancing reactivity and stability (vide supra) will likely deactivate the double bond by its electron-donating character. We postulated that $\mathrm{N}$-trifluoroethylation or $\mathrm{N}$-acylation of the nitrogen atom might reactivate the system towards nucleophiles by withdrawing electron density from the conjugated system, but the results on 14e and 16a did not support this postulate. As an intermediate in the synthetic route, ethoxycyclobutenone (12) was also tested as the ethoxy unit could serve as an improved leaving group, but to no avail. Next, bromination of the vinylic position was explored for activation, bearing in mind that this modification has been successfully applied already in Diels-Alder reactions for improving reactivity [23]. Gratifyingly, several brominated cyclobutenaminones (15d, 17a-b) inhibit MurA from E. coli at the $500 \mu \mathrm{M}$ screening concentration $(\mathrm{RA}<15 \%)$. Compounds containing amines alkylated with small substituents (15a-c) do not show any affinity to the protein, but the incorporation of the 4-methoxybenzyl group (15d) increases the affinity to $\mathrm{IC}_{50}=363 \mu \mathrm{M}$. Turning attention to electron withdrawing groups once again, it was found that $\mathrm{N}$-trifluoroethylation has no effect (15e), but the $N$-acetyl- and $N$-benzoyl-methylamino derivatives (17a and $\mathbf{1 7} \mathbf{b}$ ) substantially inhibit MurA activity. The time-dependent $\mathrm{IC}_{50}$ values of these compounds after $30 \mathrm{~min}$ are $138 \mu \mathrm{M}$ and $128 \mu \mathrm{M}$, respectively-a substantial effect for such small fragments, with the latter possessing only thirteen heavy atoms. The time dependency of the $\mathrm{IC}_{50}$ values (see Supplementary Table S1) and the enhanced electrophilicity caused by the electron-withdrawing substituents suggest a covalent mechanism of action, which was confirmed by proving the labeling on Cys115 by MS/MS measurements for both compounds (Scheme 2E,F, Supplementary Figure S1). The MIC (Minimal Inhibitory Concentrations) values for the antimicrobial action of all compounds were determined against S. aureus (ATCC 29213) and E. coli (ATCC 25922) bacterial strains. These values were $>625 \mu \mathrm{M}$, implying that although MurA inhibition is clearly related to antibiotic action, more finetuning on these structures is needed on the path to a potential new class of antibiotics.

In order to characterize this new electrophilic chemotype, the cysteine reactivity of compound 17a was evaluated in a GSH (glutathione)-based cysteine surrogate assay (Scheme 2A,B) [15]. The reaction of 17a with GSH gives an adduct in the HPLC-MS-based assay $\left(\mathrm{M}+\mathrm{H}^{+}=535 \mathrm{Da}\right.$, suggesting loss of the $\mathrm{Br}$ atom, and the conjugation reaction could be characterized with a rate constant of $\mathrm{k}_{\mathrm{GSH}}=0.0128(\mathrm{M} \mathrm{min})^{-1}$. Next, the selectivity of $17 \mathrm{a}$ was explored using a nonapeptide assay (Scheme 2C,D) [15]. The KGDYHFPIC nonapeptide contains a cysteine but also other nucleophilic residues i.e., lysine, tyrosine, aspartate, proline, and histidine. As such, the nonapeptide can help to assess the selectivity between different biologically-relevant nucleophiles. In the case of $\mathbf{1 7 a}$, only the thiol group of the oligopeptide reacts with the warhead, indicating a high degree of cysteine specificity. To evaluate if the warhead is not too reactive for standard assay conditions, the aqueous stability of the compound (17a) was also investigated in PBS buffer (pH 7.4) [15]. The stability proves to be appropriate for biological investigations, as the $t_{1 / 2}$ value for the aqueous degradation was determined to be $36.5 \mathrm{~h}$ at room temperature. The stability and bioavailability of these structures is also supported by the fact that interestingly, the rather unique bromocyclobutenaminone core has been incorporated both in the $\alpha 4 \beta 1 / \alpha 4 \beta 7$ integrin antagonist prodrug, Zaurategrast [24,25], which progressed to phase II clinical trials [26], as well as in related compounds [22]. 
A

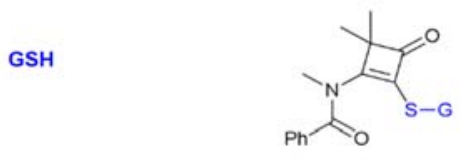

or

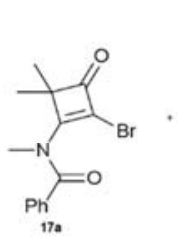

NP

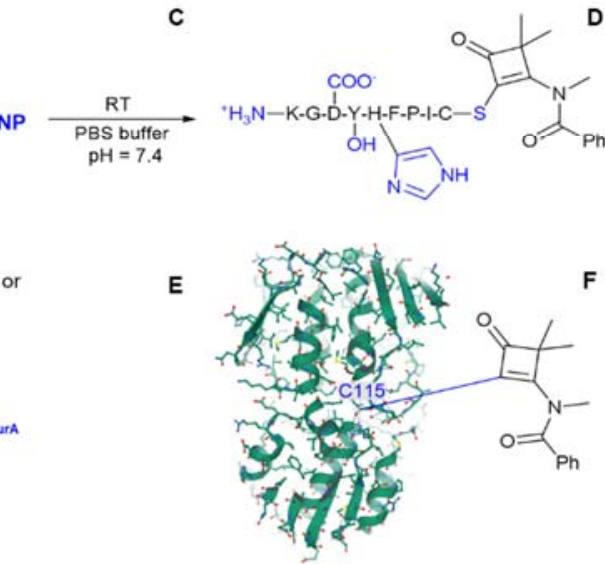

B
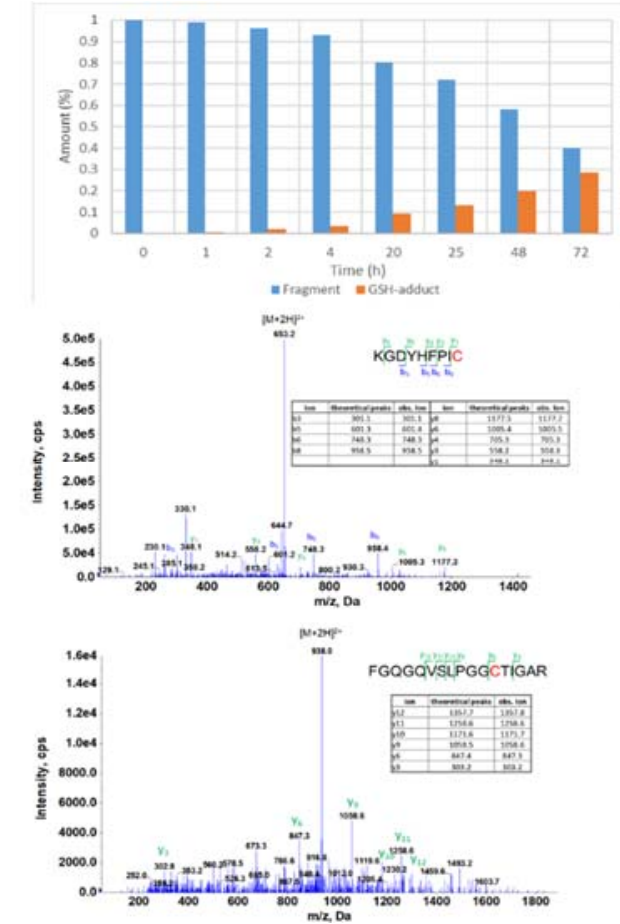

Scheme 2. Labelling of (A) glutathione (GSH), (C) KGDHFPIC nonapeptide and (E) MurA with fragment 17a together with (B) the measured consumption of the fragment (blue columns) and the increasing amount of the GSH-adduct (orange columns) in the GSH-assay, (D) the MS/MS spectrum of the Cys-labelled nonapeptide indicating the Cys-labelling together with the theoretical and observed ion peaks and (F) the MS/MS spectrum of the digested MurA fragment (amino acids 104-120) labelled on Cys115 together with the theoretical and observed ion peaks. For E the 1UAE X-ray structure has been used [27].

\section{Materials and Methods}

\subsection{Synthesis and Characterisation of Compounds}

All starting materials were obtained from commercial suppliers (primarily being Sigma-Aldrich (Swijndrecht, The Netherlands), Fluorochem (Hadfield, Derbyshire, UK) and CombiBlocks (San Diego, CA, USA)) and used without purification. Anhydrous $\mathrm{Et}_{2} \mathrm{O}$, dichloromethane (DCM), acetonitrile $(\mathrm{MeCN})$ and tetrahydrofurane (THF) were obtained by passing through an activated alumina column prior to use. All other solvents used were used as received unless otherwise stated. All reactions were carried out under a nitrogen atmosphere unless mentioned otherwise. TLC analyses were performed using Merck $\mathrm{F}_{254}$ (Merck KGaA, Darmstadt, Germany or VWR International B.V., Amsterdam, The Netherlands) aluminum-backed silica gel plates and visualized with $254 \mathrm{~nm}$ UV light or a potassium permanganate stain. Flash column chromatography was executed using Silicycle Siliaflash $\mathrm{F}_{60}$ silica gel (SiliCycle Inc., Quebec City, QC, Canada or Screening Devices, Amersfoort, The Netherlands) or by means of a Teledyne Isco CombiFlash (Teledyne Isco Inc., Lincoln, NE, USA or Beun de Ronde, Abcoude, The Netherlands) or a Biotage Isolera equipment using Biotage SNAP columns (Biotage AB, Uppsala, Sweden). All HRMS spectra were recorded on a Bruker micrOTOF mass spectrometer (Bruker Corp., Billerica, MA, USA) using ESI in positive-ion mode. All NMR spectra were recorded on either a Bruker Avance 300, Bruker Avance 500, or Bruker Avance 600 spectrometer (Bruker Corp., Billerica, MA, USA or Fällanden, Switzerland). The peak multiplicities are defined as follows: s, singlet; bs, broad singlet; $\mathrm{d}$, doublet; $\mathrm{t}$, triplet; $\mathrm{q}$, quartet; $\mathrm{p}$, pentet; dd, doublet of doublets; $\mathrm{dt}$, doublet of triplets; $\mathrm{td}$, a triplet of doublets; $\mathrm{m}$, multiplet; app, apparent. The spectra were referenced to the internal solvent peak as follows: $\mathrm{CDCl}_{3}\left({ }^{1} \mathrm{H}=7.26 \mathrm{ppm},{ }^{13} \mathrm{C}=77.16 \mathrm{ppm}\right)$, DMSO-d6 $\left({ }^{1} \mathrm{H}=2.50 \mathrm{ppm},{ }^{13} \mathrm{C}=39.52 \mathrm{ppm}\right)$. IUPAC names were adapted from ChemDraw Professional 16.0 (PerkinElmer). Purities were measured 
with the aid of analytical LC-MS using a Shimadzu LC-20AD liquid chromatography pump system (Shimadzu Corp., Kyoto, Japan or 's Hertogenbosch, The Netherlands) with a Shimadzu SPDM20A diode array detector (Shimadzu Corp., Kyoto, Japan) with the MS detection performed with a Shimadzu LC-MS-2010EV mass spectrometer (Shimadzu Corp., Kyoto, Japan) operating in both positive and negative ionization mode. The column used was an XBridge (C18) $5 \mu \mathrm{m}$ column (50 $\mathrm{mm} \times 4.6 \mathrm{~mm}$ ) (Waters Corp., Milford, MA, USA or Phenomenex, Utrecht, The Netherlands). The following solutions are used for the eluents. Solvent $\mathrm{A}: \mathrm{H}_{2} \mathrm{O}(+0.1 \% \mathrm{HCOOH})$ and solvent $\mathrm{B}$ : $\mathrm{MeCN}(+0.1 \% \mathrm{HCOOH})$. The eluent program used is as follows: flow rate: $1.0 \mathrm{~mL} / \mathrm{min}$, start $95 \% \mathrm{~A}$ in a linear gradient to $10 \%$ A over $4.5 \mathrm{~min}$, hold $1.5 \mathrm{~min}$ at $10 \% \mathrm{~A}$, in $0.5 \mathrm{~min}$ in a linear gradient to $95 \% \mathrm{~A}$, hold $1.5 \mathrm{~min}$ at $95 \%$ A, total run time: $8.0 \mathrm{~min}$. Compound purities were calculated as the percentage peak area of the analysed compound by UV detection at $254 \mathrm{~nm}$.

\subsection{GSH Reactivity and Aqueous Stability Assay}

The assay was adapted from our former publication [15].

For the glutathione assay, $500 \mu \mathrm{M}$ solution of the fragment (PBS buffer $\mathrm{pH} 7.4,10 \% \mathrm{MeCN}$, $250 \mu \mathrm{L}$ ) with $200 \mu \mathrm{M}$ solution of indoprofen (Merck KGaA, Darmstadt, Germany) as internal standard was added to $10 \mathrm{mM}$ glutathione (Merck KGaA, Darmstadt, Germany) solution (dissolved in PBS buffer, $250 \mu \mathrm{L}$ ) in a 1:1 ratio. The final concentration was $250 \mu \mathrm{M}$ fragment, $100 \mu \mathrm{M}$ indoprofen, $5 \mathrm{mM}$ glutathione and $5 \% \mathrm{MeCN}(500 \mu \mathrm{L})$. The final mixture was analyzed by HPLC-MS (Shimadzu LCMS-2020) after 0, 1, 2, 4, 20, 25, 48, $72 \mathrm{~h}$ time intervals. Degradation kinetics were also investigated respectively using the previously described method, applying pure PBS buffer instead of the glutathione solution. In this experiment, the final concentration of the mixture was $250 \mu \mathrm{M}$ fragment, $100 \mu \mathrm{M}$ indoprofen and $5 \% \mathrm{MeCN}$. The AUC (area under the curve) values were determined via integration of HPLC spectra then corrected using the internal standard. The fragment AUC values were applied for ordinary least squares (OLS) linear regression and for computing the important parameters (kinetic rate constant, half-life time) a programmed excel (Visual Basic for Applications) was utilized. The data are expressed as means of duplicate determinations, and the standard deviations were within $10 \%$ of the given values.

The calculation of the kinetic rate constant for the degradation and corrected GSH-reactivity is as follows:

The reaction half-life for pseudo-first-order reactions is $t_{1 / 2}=\ln 2 / k$, where $\mathrm{k}$ is the reaction rate. In the case of competing reactions (reaction with GSH and degradation), the effective rate for the consumption of the starting compound is $\mathrm{k}_{\mathrm{eff}}=\mathrm{k}_{\mathrm{deg}}+\mathrm{k}_{\mathrm{GSH}}$. When measuring half-lives experimentally, the $t_{1 / 2(\text { eff }}=\ln 2 /\left(k_{\text {eff }}\right)=\ln 2 /\left(k_{\text {deg }}+k_{\mathrm{GSH}}\right)$. In our case, the corrected $k_{\text {deg }}$ and $k_{\text {eff }}$ (regarding blank and GSH-containing samples, respectively) can be calculated by linear regression of the data points of the kinetic measurements. The corrected $\mathrm{k}_{\mathrm{GSH}}$ is calculated by $\mathrm{k}_{\mathrm{eff}}-\mathrm{k}_{\mathrm{deg}}$, and finally, the half-life time is determined using the equation $\mathrm{t}_{1 / 2(\mathrm{GSH})}=\ln 2 / \mathrm{k}_{\mathrm{GSH}}$.

\subsection{Oligopeptide Selectivity Assay}

The assay was adapted from our former publication [15].

For the nonapeptide assay, a $2 \mathrm{mM}$ solution of the fragment (PBS buffer $\mathrm{pH} 7.4$ with $20 \% \mathrm{MeCN}$ ) was added to $200 \mu \mathrm{M}$ nonapeptide solution (PBS buffer $\mathrm{pH}$ 7.4) in a 1:1 ratio. The final assay mixture contained $1 \mathrm{mM}$ fragment, $100 \mu \mathrm{M}$ peptide and 10\% MeCN. Based on the GSH reactivity, the applied incubation time was $24 \mathrm{~h}$.

\subsection{LC-MS/MS Measurement and Data Analysis of the Nonapeptide Reactivity Assay}

A Sciex 6500 QTRAP triple quadrupole-linear ion trap mass spectrometer, equipped with a Turbo V Source in electrospray mode (AB Sciex Pte. Ltd., Framingham, MA, USA) and an Agilent 1100 Binary Pump HPLC system (Agilent Technologies, Waldbronn, Germany) equipped with an autosampler was used for LC-MS/MS analysis. Data acquisition and processing were performed using Analyst software 
version 1.6.2 (AB Sciex Pte. Ltd., Framingham, MA, USA). Chromatographic separation was achieved by Purospher STAR RP-18 endcapped $(50 \mathrm{~mm} \times 2.1 \mathrm{~mm}, 3 \mu \mathrm{m})$ LiChocart ${ }^{\circledR} 55-2$ HPLC Cartridge (Merck KGaA, Darmstadt, Germany). The sample was eluted with gradient elution using solvent A $(0.1 \% \mathrm{HCOOH}$ in water) and solvent $\mathrm{B}(0.1 \% \mathrm{HCOOH}$ in $\mathrm{MeCN})$. Flow rate was set to $0.5 \mathrm{~mL} / \mathrm{min}$. The initial condition was $5 \%$ B for $2 \mathrm{~min}$, followed by a linear gradient to $95 \%$ B for $6 \mathrm{~min}$, followed by holding at $95 \%$ B 6-8 min; and from 8 to 8.5 min back to the initial condition with 5\% eluent B and held for $14.5 \mathrm{~min}$. The column temperature was kept at room temperature and the injection volume was $10 \mu \mathrm{L}$. Nitrogen was used as the nebulizer gas (GS1), heater gas (GS2), and curtain gas with the optimum values set at 35,45 and 45 (arbitrary units). The source temperature was $450{ }^{\circ} \mathrm{C}$ and the ion spray voltage set at $5000 \mathrm{~V}$. The declustering potential value was set to $150 \mathrm{~V}$. Information Dependent Acquisition (IDA) LC-MS/MS experiment was used to determine if the fragment binding was specific to thiol residues or not. An enhanced MS scan was applied as the survey scan and enhanced product ion (EPI) was the dependent scan. The collision energy in EPI experiments was set to $30 \mathrm{eV}$ with a collision energy spread (CES) of $10 \mathrm{~V}$. The identification of the binding position of the fragments to the nonapeptide was performed using GPMAW 4.2. software.

\subsection{Tryptic Digestion of MurA}

The tryptic digestion method was adapted from our former publication [15].

Briefly, $50 \mu \mathrm{L}$ of MurA $(42 \mu \mathrm{M})$ and $10 \mu \mathrm{L} 0.2 \%(w / v)$ RapiGest SF (Waters Corp., Milford, MA, USA) solution buffered with $50 \mathrm{mM}$ ammonium bicarbonate $\left(\mathrm{NH}_{4} \mathrm{HCO}_{3}\right)$ were mixed $(\mathrm{pH}=7.8) .4 .5 \mu \mathrm{L}$ of $45 \mathrm{mM}$ DTT ( $200 \mathrm{nmol})$ in $100 \mathrm{mM} \mathrm{NH}_{4} \mathrm{HCO}_{3}$ was added and the mixture kept at $37.5^{\circ} \mathrm{C}$ for $30 \mathrm{~min}$. After cooling the sample to room temperature, $7.5 \mu \mathrm{L}$ of $100 \mathrm{mM}$ iodoacetamide $(750 \mathrm{nmol})$ in $100 \mathrm{mM}$ $\mathrm{NH}_{4} \mathrm{HCO}_{3}$ was added and the mixture placed in the dark at room temperature for $30 \mathrm{~min}$. The reduced and alkylated protein was then digested by $10 \mu \mathrm{L}\left(1 \mathrm{mg} \mathrm{mL}^{-1}\right)$ trypsin (the enzyme-to-protein ratio was 1:10) (Sigma, St Louis, MO, USA). The sample was incubated at $37^{\circ} \mathrm{C}$ overnight. To degrade the surfactant, $7 \mu \mathrm{L}$ of $\mathrm{HCOOH}(500 \mathrm{mM})$ solution was added to the digested HDAC8 sample to obtain the final $40 \mathrm{mM}(\mathrm{pH} \approx 2)$ solution which was incubated at $37^{\circ} \mathrm{C}$ for $45 \mathrm{~min}$. For LC-MS analysis, the acid-treated sample was centrifuged for $5 \mathrm{~min}$ at 13,000 rpm.

\subsection{LC-MS/MS Measurements on Digested MurA}

A QTRAP 6500 triple quadruple-linear ion trap mass spectrometer, equipped with a Turbo $\mathrm{V}$ source in electrospray mode (AB Sciex Pte. Ltd., Framingham, MA, USA) and an Agilent 1100 Binary Pump HPLC system (Agilent Technologies, Waldbronn, Germany) equipped with an autosampler was used for LC-MS/MS analysis. Data acquisition and processing were performed using Analyst software version 1.6.2 (AB Sciex Pte. Ltd., Framingham, MA, USA). Chromatographic separation was achieved by using the Discovery ${ }^{\circledR}$ BIO Wide Pore C-18-5 $(250 \mathrm{~mm} \times 2.1 \mathrm{~mm}, 5 \mu \mathrm{m})$. The sample was eluted with a gradient of solvent $\mathrm{A}(0.1 \% \mathrm{HCOOH}$ in water) and solvent $\mathrm{B}(0.1 \% \mathrm{HCOOH}$ in $\mathrm{MeCN})$. The flow rate was set to $0.2 \mathrm{~mL} \mathrm{~min}^{-1}$. The initial conditions for separation were $5 \% \mathrm{~B}$ for $7 \mathrm{~min}$, followed by a linear gradient to $90 \%$ B for $53 \mathrm{~min}$, followed by $90 \%$ B for $3 \mathrm{~min}$; over 2 min back to the initial conditions with $5 \%$ eluent B retained for $10 \mathrm{~min}$. The injection volume was $10 \mu \mathrm{L}$ (300 pmol on the column).

An Information-Dependent Acquisiton (IDA) LC-MS/MS experiment was used to identify the modified tryptic MurA peptide fragments. Enhanced MS scan (EMS) was applied as the survey scan and an enhanced product ion (EPI) was the dependent scan. The collision energy in EPI experiments was set to rolling collision energy mode, where the actual value was set on the basis of the mass and charge state of the selected ion. Further IDA criteria: ions greater than: $400.00 \mathrm{~m} / \mathrm{z}$, which exceeds 106 counts, exclude former target ions for $30 \mathrm{~s}$ after 2 occurrence(s). In EMS and in EPI mode, the scan rate was $1000 \mathrm{Da} / \mathrm{s}$ as well. Nitrogen was used as the nebulizer gas (GS1), heater gas (GS2), and curtain gas with the optimum values set at 50, 40 and 40 (arbitrary units). The source temperature was $350^{\circ} \mathrm{C}$ and the ion spray voltage was set at $5000 \mathrm{~V}$. The declustering potential value was set to $150 \mathrm{~V}$. 
GPMAW 4.2. software was used to analyse a large number of MS-MS spectra and identify the modified tryptic MurA peptides.

\subsection{MurA Assay}

MurA $\mathrm{EC}_{\mathrm{EC}}$ protein was recombinant, expressed in E. coli. [28] The inhibition of MurA was monitored with the colorimetric malachite green method in which orthophosphate generated during the reaction is measured. MurA enzyme (E. coli) was pre-incubated with the substrate UNAG and compound for $30 \mathrm{~min}$ at $37^{\circ} \mathrm{C}$. The reaction was started by the addition of the second substrate PEP, resulting in a mixture with a final volume of $50 \mu \mathrm{L}$. The mixtures contained: $50 \mathrm{mM}$ Hepes, $\mathrm{pH} 7.8,0.005 \%$ Triton X-114, $200 \mu \mathrm{M}$ UNAG, $100 \mu \mathrm{M}$ PEP, purified MurA (diluted in $50 \mathrm{mM}$ Hepes, pH 7.8) and $500 \mu \mathrm{M}$ of each tested compound dissolved in DMSO. All compounds were soluble in the assay mixtures containing $5 \%$ DMSO $(v / v)$. After incubation for $15 \mathrm{~min}$ at $37^{\circ} \mathrm{C}$, the enzyme reaction was terminated by adding Biomol ${ }^{\circledR}$ reagent $(100 \mu \mathrm{L})$ and the absorbance was measured at $650 \mathrm{~nm}$ after $5 \mathrm{~min}$. All of the experiments were run in duplicate. Remaining activities (RAs) were calculated with respect to similar assays without the tested compounds and with $5 \%$ DMSO. The $\mathrm{IC}_{50}$ values, the concentration of the compound at which the remaining activity was $50 \%$, were determined by measuring the remaining activities at seven different compound concentrations. The data are expressed as means of duplicate determinations, and the standard deviations were within $10 \%$ of the given values. A time-dependent inhibition assay was also performed. The $\mathrm{IC}_{50}$ values were determined at 0,15 and 30 min of pre-incubation.

\subsection{Antimicrobial Testing (MIC Determination)}

Antimicrobial testing was carried out by the broth microdilution method in 96-well plate format following the CLSI guidelines and European Committee for Antimicrobial Susceptibility Testing recommendations. Bacterial suspension of specific bacterial strain, equivalent to $0.5 \mathrm{McFarland}$ turbidity standard, was diluted with cation-adjusted Mueller Hinton broth to obtain a final inoculum of $10^{5} \mathrm{CFU} / \mathrm{mL}$. Compounds dissolved in DMSO and inoculum were mixed together and incubated for $20-24 \mathrm{~h}$ at $37^{\circ} \mathrm{C}$. After incubation the minimal inhibitory concentration (MIC) values were determined by visual inspection as the lowest dilution of compounds showing no turbidity. The MICs were determined against S. aureus (ATCC 29213) and E. coli (ATCC 25922) bacterial strains. Tetracycline was used as a positive control on every assay plate, showing a MIC of $0.5 \mu \mathrm{g} / \mathrm{mL}$ and $1 \mu \mathrm{g} / \mathrm{mL}$ for S. aureus and E. coli, respectively.

\subsection{Chemical Syntheses}

\section{3-Ethoxy-4,4-dimethylcyclobut-2-en-1-one (12)}

To a stirred solution of isobutyryl chloride $(10.7 \mathrm{~mL}, 102 \mathrm{mmol})$ and ethoxyacetylene $11(50.0 \mathrm{~mL}$, $205 \mathrm{mmol}, 40 \% \mathrm{wt}$ in hexanes) in $\mathrm{Et}_{2} \mathrm{O}(128 \mathrm{~mL}), \mathrm{Et}_{3} \mathrm{~N}(21.4 \mathrm{~mL}, 154 \mathrm{mmol})$ was added slowly over $5 \mathrm{~min}$. The mixture was stirred at $\mathrm{rt}$ for $30 \mathrm{~min}$ before being heated at $40{ }^{\circ} \mathrm{C}$ for $24 \mathrm{~h}$. The mixture was then allowed to cool. The precipitate was filtered and the filtrate was concentrated in vacuo. The crude product was purified over silica gel with a gradient of $10-40 \% \mathrm{EtOAc} / \mathrm{cHex}$ to afford the title compound $2(8.90 \mathrm{~g}, 62 \%$ yield) as a yellow oil.

${ }^{1} \mathrm{H}$ NMR $(500 \mathrm{MHz}$, Chloroform- $d) \delta 4.78(\mathrm{~s}, 1 \mathrm{H}), 4.21(\mathrm{q}, J=7.1 \mathrm{~Hz}, 2 \mathrm{H}), 1.45(\mathrm{t}, J=7.1 \mathrm{~Hz}, 3 \mathrm{H})$, 1.24 (s, 6H). ${ }^{13} \mathrm{C}$ NMR (126 MHz, Chloroform- $d$ ) $\delta$ 194.1, 190.4, 102.4, 69.4, 60.1, 19.7, 14.3. LC-MS: $\mathrm{RT}=3.33 \mathrm{~min}, 99+\%(254 \mathrm{~nm}), \mathrm{m} / z[\mathrm{M}+\mathrm{H}]^{+}=141$. HRMS calculated for $\mathrm{C}_{8} \mathrm{H}_{13} \mathrm{O}_{2}{ }^{+}[\mathrm{M}+\mathrm{H}]^{+}=141.0910$, found 141.0923.

\section{2,2-Dimethylcyclobutane-1,3-dione (13)}

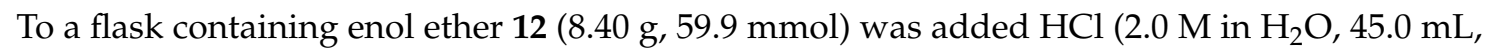
$90.0 \mathrm{mmol}$ ) in one portion and the mixture was stirred vigorously at $\mathrm{rt}$ for $24 \mathrm{~h}$. The product was 
extracted with DCM (3x). The organic layers were combined, dried over $\mathrm{MgSO}_{4}$, and concentrated in vacuo to afford the title compound $3(6.20 \mathrm{~g}, 92 \%$ yield $)$ as a flaky brown solid.

${ }^{1} \mathrm{H}$ NMR (600 MHz, Chloroform- $d$ ) $\delta 3.92(\mathrm{~s}, 2 \mathrm{H}), 1.28$ (s, 6H). ${ }^{13} \mathrm{C}$ NMR (151 MHz, Chloroform- $d$ ) $\delta$ 207.0, 73.0, 60.4, 17.6. LC-MS: RT $=1.78 \mathrm{~min}, 98 \%(254 \mathrm{~nm}), \mathrm{m} / z[\mathrm{M}+\mathrm{H}]^{+}=113$. HRMS calculated for $\mathrm{C}_{6} \mathrm{H}_{9} \mathrm{O}_{2}{ }^{+}[\mathrm{M}+\mathrm{H}]^{+}=113.0597$, found 113.0603.

\subsection{General Procedure A: Enaminone Formation}

To a solution of dione 13 (1.0 eq) in THF ( $0.50 \mathrm{M})$ was added amine (1.1 eq), $\mathrm{AcOH}$ (1.1 eq) and a spatula of $\mathrm{Na}_{2} \mathrm{SO}_{4}$. The reaction mixture was stirred at $65{ }^{\circ} \mathrm{C}$ for the indicated time. The reaction mixture was allowed to cool to rt. The solids were filtered and the filtrate concentrated in vacuo. The residue was taken up in EtOAc and washed with satd. aq. $\mathrm{Na}_{2} \mathrm{CO}_{3}$ and brine. The organic layer was dried over $\mathrm{Na}_{2} \mathrm{SO}_{4}$, filtered and concentrated in vacuo. The crude product was purified over silica gel using the indicated gradient of $\mathrm{MeOH} / \mathrm{DCM}$ to afford the product enaminone.

3-(Methylamino)-4,4-dimethylcyclobut-2-en-1-one (14a)

This compound was prepared according to General Procedure A using dione 13 (388 $\mathrm{mg}$, $3.46 \mathrm{mmol}), \mathrm{MeNH}_{2}(2.0 \mathrm{M}$ in THF, $1.90 \mathrm{~mL}, 3.81 \mathrm{mmol})$ and a reaction time of $40 \mathrm{~h}$. Purification over silica gel using a gradient of $0-10 \% \mathrm{MeOH} / \mathrm{DCM}$ afforded the title compound $14 \mathrm{a}(350 \mathrm{mg}, 81 \%)$ as a pale brown solid.

Rotamers are observed in ratio ca. 1.0:0.1 in Chloroform- $d$. Only peaks corresponding to the major rotamer are reported. ${ }^{1} \mathrm{H}$ NMR $(500 \mathrm{MHz}$, Chloroform- $d) \delta 5.63(\mathrm{br} \mathrm{s}, 1 \mathrm{H}), 4.59(\mathrm{~s}, 1 \mathrm{H})$, $2.99(\mathrm{~d}, J=5.0 \mathrm{~Hz}, 3 \mathrm{H}), 1.24(\mathrm{~s}, 6 \mathrm{H}) .{ }^{13} \mathrm{C}$ NMR $(126 \mathrm{MHz}$, Chloroform-d) $\delta$ 192.2, 178.8, 95.7, 58.5, 31.8, 20.3. LC-MS: $\mathrm{RT}=3.20 \mathrm{~min}, 99+\%(254 \mathrm{~nm}), \mathrm{m} / z[\mathrm{M}+\mathrm{H}]^{+}=126$. HRMS calculated for $\mathrm{C}_{7} \mathrm{H}_{12} \mathrm{NO}^{+}[\mathrm{M}+\mathrm{H}]^{+}=126.0913$, found 126.0912.

3-(Dimethylamino)-4,4-dimethylcyclobut-2-en-1-one (14b)

This compound was prepared according to General Procedure A using dione 13 (200 mg, $1.78 \mathrm{mmol}), \mathrm{Me}_{2} \mathrm{NH}(2.0 \mathrm{M}$ in THF, $0.20 \mathrm{~mL}, 1.96 \mathrm{mmol})$ and a reaction time of $40 \mathrm{~h}$. Purification over silica gel using a gradient of $0-10 \% \mathrm{MeOH} / \mathrm{DCM}$ afforded the title compound $\mathbf{1 4 b}$ (191 $\mathrm{mg}, 77 \%$ yield) as a brown crystalline solid.

Rotamers are observed in ratio 1.0:1.0 in Chloroform- $d$. All peaks for both rotamers are reported. ${ }^{1} \mathrm{H}$ NMR (500 MHz, Chloroform-d) $\delta 4.53(\mathrm{~s}, 1 \mathrm{H}), 3.07$ (s, 3H), $2.99(\mathrm{~s}, 3 \mathrm{H}), 1.32(\mathrm{~s}, 6 \mathrm{H}) .{ }^{13} \mathrm{C}$ NMR $(126 \mathrm{MHz}$, Chloroform-d) $\delta 190.9,178.4,96.0,58.2,40.1,39.4,21.2$. LC-MS: RT $=2.34 \mathrm{~min}, 99+\%$ $(254 \mathrm{~nm}), m / z[\mathrm{M}+\mathrm{H}]^{+}=140$. HRMS calculated for $\mathrm{C}_{8} \mathrm{H}_{14} \mathrm{NO}^{+}[\mathrm{M}+\mathrm{H}]^{+}=140.1064$, found 140.1066

3-(Diethylamino)-4,4-dimethylcyclobut-2-en-1-one (14c)

This compound was prepared according to General Procedure A using dione $\mathbf{1 3}$ (200 mg, $1.78 \mathrm{mmol}), \mathrm{Et}_{2} \mathrm{NH}(0.20 \mathrm{~mL}, 1.96 \mathrm{mmol})$ and a reaction time of $40 \mathrm{~h}$, followed by an additional portion of $\mathrm{Et}_{2} \mathrm{NH}(0.10 \mathrm{~mL}, 0.89 \mathrm{mmol})$ and stirring for a further $5 \mathrm{~h}$. Purification over silica gel using a gradient of $0-10 \% \mathrm{MeOH} / \mathrm{DCM}$ afforded the title compound $14 \mathrm{c}(175 \mathrm{mg}, 59 \%$ yield) as a brown oil.

Rotamers are observed in ratio 1.0:1.0 in Chloroform- $d$. All peaks for both rotamers are reported. ${ }^{1} \mathrm{H}$ NMR (500 MHz, Chloroform- $\left.d\right) \delta 4.54(\mathrm{~s}, 1 \mathrm{H}), 3.34(\mathrm{q}, J=7.2 \mathrm{~Hz}, 2 \mathrm{H}), 3.27(\mathrm{q}, J=7.2 \mathrm{~Hz}, 2 \mathrm{H})$, $1.33(\mathrm{~s}, 6 \mathrm{H}), 1.25(\mathrm{t}, J=7.2 \mathrm{~Hz}, 3 \mathrm{H}), 1.22(\mathrm{t}, J=7.2 \mathrm{~Hz}, 3 \mathrm{H}) .{ }^{13} \mathrm{C}$ NMR $(126 \mathrm{MHz}$, Chloroform-d) $\delta 190.9$, $177.5,95.6,58.4,44.6,44.1,21.4,14.2,12.3$. LC-MS: RT $=3.06 \mathrm{~min}, 99+\%(254 \mathrm{~nm}), \mathrm{m} / z[\mathrm{M}+\mathrm{H}]^{+}=168$. HRMS calculated for $\mathrm{C}_{10} \mathrm{H}_{18} \mathrm{NO}^{+}[\mathrm{M}+\mathrm{H}]^{+}=168.1377$, found 168.1382 .

3-((4-Methoxybenzyl)(methyl)amino)-4,4-dimethylcyclobut-2-en-1-one (14d)

This compound was prepared according to General Procedure A using dione 13 (200 $\mathrm{mg}$, $1.78 \mathrm{mmol})$, (4-methoxybenzyl)- $\mathrm{N}$-methylamine $(0.29 \mathrm{~mL}, 1.96 \mathrm{mmol})$ and a reaction time of $40 \mathrm{~h}$. Purification over silica gel using a gradient of $0-10 \% \mathrm{MeOH} / \mathrm{DCM}$ afforded the title compound 14d (330 $\mathrm{mg}, 75 \%$ yield) as a viscous brown oil. 
Rotamers are observed in ratio 1.0:1.0 in Chloroform- $d$. All peaks for both rotamers are reported. ${ }^{1} \mathrm{H}$ NMR $(600 \mathrm{MHz}$, Chloroform-d) $\delta 7.18-7.12(\mathrm{~m}, 2 \mathrm{H}), 6.93-6.88(\mathrm{~m}, 2 \mathrm{H}), 4.70(\mathrm{~s}, 1 \mathrm{H}), 4.59(\mathrm{~s}, 1 \mathrm{H})$, $4.42(\mathrm{~s}, 2 \mathrm{H}), 4.29(\mathrm{~s}, 2 \mathrm{H}), 3.82(\mathrm{~s}, 3 \mathrm{H}), 3.81(\mathrm{~s}, 3 \mathrm{H}), 2.95(\mathrm{~s}, 3 \mathrm{H}), 2.80(\mathrm{~s}, 3 \mathrm{H}), 1.38(\mathrm{~s}, 6 \mathrm{H}), 1.34(\mathrm{~s}, 6 \mathrm{H})$. ${ }^{13} \mathrm{C}$ NMR (151 MHz, Chloroform-d) $\delta 190.9,190.8,178.4,178.3,159.6,129.1,128.7,126.9,126.7,114.5$, $114.4,96.2,95.9,58.4,58.3,56.2,55.4,55.4,55.3,36.6,36.3,21.4,21.1$. LC-MS: RT $=3.62 \mathrm{~min}, 99+\%$ $(254 \mathrm{~nm}), m / z[\mathrm{M}+\mathrm{H}]^{+}=246$. HRMS calculated for $\mathrm{C}_{15} \mathrm{H}_{20} \mathrm{NO}_{2}{ }^{+}[\mathrm{M}+\mathrm{H}]^{+}=246.1489$, found 246.1489 .

4,4-Dimethyl-3-(methyl(2,2,2-trifluoroethyl)amino)cyclobut-2-en-1-one (14e)

This compound was prepared according to General Procedure A using dione 13 (140 mg, $1.25 \mathrm{mmol}),(2,2,2$-trifluoroethyl)-methylamine $(0.14 \mathrm{~mL}, 1.37 \mathrm{mmol})$ and a reaction time of $16 \mathrm{~h}$. Purification over silica gel using a gradient of $0-10 \% \mathrm{MeOH} / \mathrm{DCM}$ afforded the title compound 14e (197 mg, 76\% yield) as a brown oil.

Rotamers are observed in ratio 1.0:0.8 in Chloroform- $d$. All peaks for both rotamers are reported. ${ }^{1} \mathrm{H}$ NMR (500 MHz, Chloroform- $d$ ) $\delta 4.67(\mathrm{~s}, 1 \mathrm{H}), \delta 4.70(\mathrm{~s}, 1 \mathrm{H}), 3.80(\mathrm{q}, J=8.6 \mathrm{~Hz}, 2 \mathrm{H}), 3.75(\mathrm{q}, J=9.0 \mathrm{~Hz}$, 2H), $3.20(\mathrm{~s}, 3 \mathrm{H}), 3.09-3.10(\mathrm{~m}, 3 \mathrm{H}), 1.35(\mathrm{~s}, 6 \mathrm{H}), 1.32(\mathrm{~s}, 6 \mathrm{H}) .{ }^{13} \mathrm{C}$ NMR $(151 \mathrm{MHz}$, Chloroform-d) $\delta 190.63$, $179.51,179.47,124.47(q, J=281.9 \mathrm{~Hz}), 123.70(\mathrm{q}, J=281.9 \mathrm{~Hz}), 99.72,99.03,54.29(\mathrm{q}, J=34.1 \mathrm{~Hz})$, $53.51(q, J=34.1 \mathrm{~Hz}), 39.06,21.19,21.08$. LC-MS: RT $=3.30 \mathrm{~min}, 99+\%(254 \mathrm{~nm}), \mathrm{m} / z[\mathrm{M}+\mathrm{H}]^{+}=208$. HRMS calculated for $\mathrm{C}_{9} \mathrm{H}_{13} \mathrm{~F}_{3} \mathrm{NO}^{+}[\mathrm{M}+\mathrm{H}]^{+}=208.0944$, found 208.0947.

\subsection{General Procedure B: Bromination}

A solution of enaminone (1.0 eq) and $\mathrm{Et}_{3} \mathrm{~N}(2.0 \mathrm{eq})$ in $\mathrm{THF}(0.10 \mathrm{M})$ at $0{ }^{\circ} \mathrm{C}$ was treated dropwise with a solution of $\mathrm{Br}_{2}(1.1 \mathrm{eq})$ in THF $(2.0 \mathrm{~mL})$. The reaction mixture was stirred at $0{ }^{\circ} \mathrm{C}$ for the indicated time. The mixture was diluted with EtOAc and washed with satd. aq. $\mathrm{NaHCO}_{3}$ and brine. The organic layer was dried over $\mathrm{MgSO}_{4}$, filtered and concentrated in vacuo. The crude product was purified over silica gel using the indicated gradient of $\mathrm{MeOH} / \mathrm{EtOAc}$ followed by reversed-phase chromatography on $\mathrm{C} 18$ silica gel using the indicated gradient of $\mathrm{MeCN} / \mathrm{H}_{2} \mathrm{O}$ to afford the product bromoenaminone.

2-Bromo-4,4-dimethyl-3-(methylamino)cyclobut-2-en-1-one (15a)

This compound was prepared according to General Procedure B using enaminone 14a $(80 \mathrm{mg}$, $0.64 \mathrm{mmol}$ ) and a reaction time of $1 \mathrm{~h}$. Purification over silica gel using a gradient of $0-10 \% \mathrm{MeOH} / \mathrm{EtOAc}$ and over reversed-phase C18 silica gel using a gradient of $0-100 \% \mathrm{MeCN} / \mathrm{H}_{2} \mathrm{O}(+0.1 \% \mathrm{HCOOH})$ afforded the title compound 15a (81 mg, 62\% yield) as a pale yellow solid.

Rotamers are observed in ratio 1.0:0.6 in Chloroform- $d$. All peaks for both rotamers are reported. ${ }^{1} \mathrm{H}$ NMR (600 MHz, Chloroform-d) $\delta 5.97$ (br s, 1H), 5.55 (br s, 1H), 3.30 (d, J = 5.2 Hz, 3H), 3.12 $(\mathrm{d}, J=5.2 \mathrm{~Hz}, 3 \mathrm{H}), 1.38(\mathrm{~s}, 6 \mathrm{H}), 1.24(\mathrm{~s}, 6 \mathrm{H}) .{ }^{13} \mathrm{C} \mathrm{NMR}(151 \mathrm{MHz}$, Chloroform-d $) \delta 187.8,185.9,177.6,175.5$, 72.8, 70.5, 59.1, 58.7, 31.6, 31.4, 20.8, 19.9. LC-MS: RT = $2.80 \mathrm{~min}, 99+\%(254 \mathrm{~nm}), \mathrm{m} / z[\mathrm{M}+\mathrm{H}]^{+}=204$ (light isotope). HRMS calculated for $\mathrm{C}_{7} \mathrm{H}_{11} \mathrm{NOBr}^{+}[\mathrm{M}+\mathrm{H}]^{+}=205.9998$ (heavy isotope), found 205.9997 .

2-Bromo-4,4-dimethyl-3-(methylamino)cyclobut-2-en-1-one (15b)

This compound was prepared according to General Procedure B using enaminone $\mathbf{1 4 b}(80 \mathrm{mg}$, $0.58 \mathrm{mmol}$ ) and a reaction time of $1 \mathrm{~h}$. Purification over silica gel using a gradient of $0-10 \% \mathrm{MeOH} / \mathrm{EtOAc}$ and over reversed-phase C18 silica gel using a gradient of $0-100 \% \mathrm{MeCN} / \mathrm{H}_{2} \mathrm{O}(+0.1 \% \mathrm{HCOOH})$ afforded the title compound $\mathbf{1 5 b}$ (59 $\mathrm{mg}, 47 \%$ yield) as a pale yellow solid.

Rotamers are observed in ratio 1.0:1.0 in Chloroform- $d$. All peaks for both rotamers are reported. ${ }^{1} \mathrm{H}$ NMR (600 MHz, Chloroform-d) $\delta 3.35$ (s, 3H), 3.07 (s, 3H), $1.32(\mathrm{~s}, 6 \mathrm{H}) .{ }^{13} \mathrm{C} \mathrm{NMR}$ $(151 \mathrm{MHz}$, Chloroform- $d) \delta 186.5,174.5,70.3,58.7,40.7,39.6,20.9$. LC-MS: RT $=3.06 \mathrm{~min}, 99+\%$ $(254 \mathrm{~nm}), m / z[\mathrm{M}+\mathrm{H}]^{+}=218$ (light isotope). HRMS calculated for $\mathrm{C}_{8} \mathrm{H}_{13} \mathrm{NOBr}^{+}[\mathrm{M}+\mathrm{H}]^{+}=218.0175$ (light isotope), found 218.0182. 
2-Bromo-3-(diethylamino)-4,4-dimethylcyclobut-2-en-1-one (15c)

This compound was prepared according to General Procedure B using enaminone $14 \mathrm{c}(80 \mathrm{mg}$, $0.48 \mathrm{mmol}$ ) and a reaction time of $1 \mathrm{~h}$. Purification over silica gel using a gradient of $0-10 \% \mathrm{MeOH} / \mathrm{EtOAc}$ and over reversed-phase C18 silica gel using a gradient of $0-100 \% \mathrm{MeCN} / \mathrm{H}_{2} \mathrm{O}(+0.1 \% \mathrm{HCOOH})$ afforded the title compound $15 \mathrm{c}$ ( $49 \mathrm{mg}, 42 \%$ yield) as a colourless oil.

Rotamers are observed in ratio 1.0:1.0 in Chloroform- $d$. All peaks for both rotamers are reported. ${ }^{1} \mathrm{H}$ NMR $(600 \mathrm{MHz}$, Chloroform- $d) \delta 3.64(\mathrm{q}, J=7.2 \mathrm{~Hz}, 1 \mathrm{H}), 3.35(\mathrm{q}, J=7.2 \mathrm{~Hz}, 1 \mathrm{H}), 1.30(\mathrm{t}, J=7.2 \mathrm{~Hz}$, $3 \mathrm{H}), 1.28(\mathrm{t}, J=7.2 \mathrm{~Hz}, 3 \mathrm{H}) .{ }^{13} \mathrm{C}$ NMR $(151 \mathrm{MHz}$, Chloroform- $d$ ) $\delta 186.6,173.9,69.7,58.8,45.7,43.0,21.1$, 14.4, 14.2. LC-MS: $\mathrm{RT}=3.78 \mathrm{~min}, 97 \%(254 \mathrm{~nm}), \mathrm{m} / z[\mathrm{M}+\mathrm{H}]^{+}=248$ (heavy isotope). HRMS calculated for $\mathrm{C}_{10} \mathrm{H}_{17} \mathrm{NOBr}^{+}[\mathrm{M}+\mathrm{H}]^{+}=246.0488$ (light isotope), found 246.0488 .

2-Bromo-3-((4-methoxybenzyl)(methyl)amino)-4,4-dimethylcyclobut-2-en-1-one (15d)

This compound was prepared according to General Procedure B using enaminone 14d (100 mg, $0.41 \mathrm{mmol}$ ) and a reaction time of $2 \mathrm{~h}$. Purification over silica gel using a gradient of $0-10 \% \mathrm{MeOH} / \mathrm{EtOAc}$ and over reversed-phase $\mathrm{C} 18$ silica gel using a gradient of $0-100 \% \mathrm{MeCN} / \mathrm{H}_{2} \mathrm{O}(+0.1 \% \mathrm{HCOOH})$ afforded the title compound $15 \mathrm{~d}$ ( $51 \mathrm{mg}$, 39\% yield) as a pale yellow oil.

Rotamers are observed in ratio 1:0.6 in Chloroform- $d$. All peaks for both rotamers are reported. ${ }^{1} \mathrm{H}$ NMR (600 MHz, Chloroform-d) 8 7.25-7.22 (m, 2H), 7.17-7.14 (m, 2H), 6.95-6.91 (m, 4H), 4.75 (s, 2H), $4.41(\mathrm{~s}, 2 \mathrm{H}), 3.82(\mathrm{~s}, 3 \mathrm{H}), 3.82(\mathrm{~s}, 3 \mathrm{H}), 3.16(\mathrm{~s}, 3 \mathrm{H}), 2.95(\mathrm{~s}, 3 \mathrm{H}), 1.39(\mathrm{~s}, 6 \mathrm{H}), 1.35(\mathrm{~s}, 6 \mathrm{H}) .{ }^{13} \mathrm{C}$ NMR $(151 \mathrm{MHz}$, Chloroform-d) $\delta 186.71,186.68,174.72,174.28,159.90,159.82,129.52,128.88,127.15$, 125.90, 114.70, 114.60, 70.51, 70.45, 58.96, 58.93, 56.64, 55.50, 55.47, 54.65, 37.43, 36.27, 21.23, 20.94 . LC-MS: $\mathrm{RT}=4.24 \mathrm{~min}, 99+\%(254 \mathrm{~nm}), \mathrm{m} / z[\mathrm{M}+\mathrm{H}]^{+}=324$ (light isotope). HRMS calculated for $\mathrm{C}_{15} \mathrm{H}_{19} \mathrm{NO}_{2} \mathrm{Br}^{+}[\mathrm{M}+\mathrm{H}]^{+}=326.0573$ (heavy isotope), found 326.0573 .

2-Bromo-4,4-dimethyl-3-(methyl(2,2,2-trifluoroethyl)amino)cyclobut-2-en-1-one (15e)

This compound was prepared according to General Procedure B using enaminone 14e $(80 \mathrm{mg}$, $0.39 \mathrm{mmol}$ ) and a reaction time of $1 \mathrm{~h}$. Purification over silica gel using a gradient of $0-10 \% \mathrm{MeOH} / \mathrm{EtOAc}$ and over reversed-phase $\mathrm{C} 18$ silica gel using a gradient of $0-100 \% \mathrm{MeCN} / \mathrm{H}_{2} \mathrm{O}(+0.1 \% \mathrm{HCOOH})$ afforded the title compound $15 \mathrm{e}$ (32\% yield) as a pale yellow solid.

Rotamers are observed in ratio 1:0.4 in Chloroform- $d$. All peaks for both rotamers are reported. ${ }^{1} \mathrm{H}$ NMR $(600 \mathrm{MHz}$, Chloroform- $d) \delta 4.27(\mathrm{q}, J=8.3 \mathrm{~Hz}, 2 \mathrm{H}), 3.79(\mathrm{q}, J=8.3 \mathrm{~Hz}, 2 \mathrm{H}), 3.46(\mathrm{~s}, 3 \mathrm{H})$, $3.22(\mathrm{~s}, 3 \mathrm{H}), 1.37(\mathrm{~s}, 6 \mathrm{H}), 1.34(\mathrm{~s}, 6 \mathrm{H}) .{ }^{13} \mathrm{C}$ NMR $(151 \mathrm{MHz}$, Chloroform-d) $\delta 186.51,175.87,175.66$, $123.95(\mathrm{q}, J=282.1 \mathrm{~Hz}), 123.51(\mathrm{q}, J=282.1 \mathrm{~Hz}), 74.86,74.20,59.70,59.61,54.57(\mathrm{q}, J=34.0 \mathrm{~Hz}), 52.41$ $(\mathrm{q}, J=34.0 \mathrm{~Hz}), 40.05,39.13,20.93,20.84$. LC-MS: RT $=3.86 \mathrm{~min}, 99+\%(254 \mathrm{~nm}), \mathrm{m} / z[\mathrm{M}+\mathrm{H}]^{+}=286$ (light isotope). HRMS calculated for $\mathrm{C}_{9} \mathrm{H}_{12} \mathrm{NOF}_{2} \mathrm{Br}^{+}[\mathrm{M}+\mathrm{H}]^{+}=286.0049$ (light isotope), found 286.0044 .

\subsection{General Procedure C: Enaminone N-Acylation}

To a solution of enaminone $(1.0 \mathrm{eq})$ in $\operatorname{THF}(0.025 \mathrm{M})$ at $-78^{\circ} \mathrm{C}$ was added $\mathrm{NaN}\left(\mathrm{SiMe}_{3}\right)_{2}(1.0 \mathrm{M}$ in THF, $1.5 \mathrm{eq}$ ) dropwise. The mixture was stirred at this temperature for $90 \mathrm{~min}$ before dropwise addition of the acid chloride (1.2 eq). The reaction mixture was stirred for a further $2 \mathrm{~h}$ at $-78^{\circ} \mathrm{C}$. Brine was added slowly at this temperature whilst stirring vigorously and the mixture was allowed to warm to rt. The volatiles were removed in vacuo and the residue was partitioned between EtOAc and water. The organic layer was washed with brine, dried over $\mathrm{Na}_{2} \mathrm{SO}_{4}$, and concentrated in vacuo. The crude product was purified over silica gel to afford the product $N$-acyl-enaminone.

$\mathrm{N}$-(4,4-dimethyl-3-oxocyclobut-1-en-1-yl)- $\mathrm{N}$-methylbenzamide (16a)

This compound was prepared according to General Procedure $C$ using enaminone 14a $(80 \mathrm{mg}$, $0.64 \mathrm{mmol})$ and $\mathrm{BzCl}(0.09 \mathrm{~mL}, 0.77 \mathrm{mmol})$. Purification over silica gel using a gradient of $20-80 \%$ $\mathrm{EtOAc/cHex}$ afforded the title compound $16 \mathrm{a}$ (72\% yield) as a white solid. 
No significant rotamers are observed in NMR spectra. ${ }^{1} \mathrm{H}$ NMR $(500 \mathrm{MHz}$, Chloroform- $d$ )

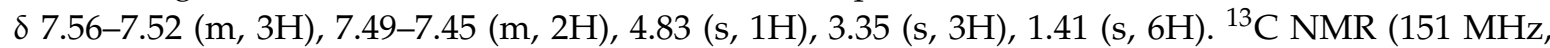
Chloroform-d) $\delta 194.2,175.9,171.1,134.1,132.0,129.0,127.9,111.8,62.7,36.7,21.4$. LC-MS: RT $=3.85 \mathrm{~min}$, $99 \%(254 \mathrm{~nm}), m / z[\mathrm{M}+\mathrm{H}]^{+}=230$. HRMS calculated for $\mathrm{C}_{14} \mathrm{H}_{16} \mathrm{NO}_{2}{ }^{+}[\mathrm{M}+\mathrm{H}]^{+}=230.1176$ found 230.1171 .

The regiochemistry of the acylation (i.e., acylation of $\mathrm{N}$ atom and not of vinyl position) was proven by $2 \mathrm{D}$ NMR (HSQC $+\mathrm{HMBC}$ ) - the singlet signal counting for $1 \mathrm{H}$ has an associated ${ }^{13} \mathrm{C}$ signal in HSQC and thus the vinyl position remains unsubstituted in the product.

$N$-(2-bromo-4,4-dimethyl-3-oxocyclobut-1-en-1-yl)-N-methylbenzamide (17a)

This compound was prepared according to General Procedure $\mathrm{C}$ using bromoenaminone 15a $(80 \mathrm{mg}, 0.39 \mathrm{mmol})$ and $\mathrm{BzCl}(0.06 \mathrm{~mL}, 0.47 \mathrm{mmol})$. Purification over silica gel using a gradient of $20-70 \%$ EtOAc/cHex afforded the title compound 17 a ( $86 \mathrm{mg}, 71 \%$ yield) as a white solid.

No significant rotamers are observed in NMR spectra. ${ }^{1} \mathrm{H}$ NMR $(600 \mathrm{MHz}$, Chloroform- $d$ ) $\delta$ 7.62-7.54 (m, 3H), 7.53-7.46 (m, 2H), $3.61(\mathrm{~s}, 3 \mathrm{H}), 1.43(\mathrm{~s}, 6 \mathrm{H}) .{ }^{13} \mathrm{C}$ NMR (151 MHz, Chloroform- $d$ ) $\delta$ 191.4, 174.6, 170.1, 133.5, 132.5, 129.1, 128.5, 87.8, 63.5, 39.0, 21.2. LC-MS: RT $=4.55 \mathrm{~min}, 99+\%$ $(254 \mathrm{~nm}), m / z[\mathrm{M}+\mathrm{H}]^{+}=308$ (light isotope). HRMS calculated for $\mathrm{C}_{14} \mathrm{H}_{15} \mathrm{BrNO}_{2}{ }^{+}[\mathrm{M}+\mathrm{H}]^{+}=310.0260$ (heavy isotope), found 310.0254 .

$\mathrm{N}$-(2-bromo-4,4-dimethyl-3-oxocyclobut-1-en-1-yl)- $\mathrm{N}$-methylacetamide (17b)

This compound was prepared according to General Procedure $C$ using bromoenaminone 15a $(6 \mathrm{mg}, 0.03 \mathrm{mmol})$ and $\mathrm{AcCl}(0.002 \mathrm{~mL}, 0.03 \mathrm{mmol})$. Extraction with $\mathrm{DCM}(5 \mathrm{~mL})$ and water $(2 \times 1 \mathrm{~mL})$ afforded the title compound $\mathbf{1 7 b}$ ( $5.9 \mathrm{mg}, 80 \%$ yield) as a white solid.

No significant rotamers are observed in NMR spectra. ${ }^{1} \mathrm{H}$ NMR (500 MHz, DMSO-d6) $\delta 3.19$ (s, 3H), 1.90 (s, 3H), 1.11 (s, 6H). ${ }^{13} \mathrm{C}$ NMR (125 MHz, DMSO-d6) $\delta ~ 186.3, ~ 184.9, ~ 175.3,68.7,40.9,30.5$, 20.8, 20.1. LC-MS: RT $1.53 \mathrm{~min}, 97 \%(254 \mathrm{~nm}), \mathrm{m} / z[\mathrm{M}+\mathrm{H}]^{+}=246$ (heavy isotope). HRMS calculated for deacetylated $\mathrm{C}_{7} \mathrm{H}_{11} \mathrm{BrNO}^{+}[\mathrm{M} \text {-acetyl }+\mathrm{H}]^{+}=204.0018$ (light isotope), found 204.0018.

\section{Conclusions}

A new electrophilic warhead chemotype, the bromocyclobutenaminone scaffold, was designed as a thiol-labelling agent. It was shown that the incorporation of the bromine atom in the cyclobutenaminone core, sometimes in conjunction with an electron withdrawing group on the nitrogen atom, turns the inactive fragments into novel and useful covalent probes. The investigation of a set of compounds against MurA protein from E. coli led to the identification of fragments with moderate inhibitory activity. These compounds represent promising starting points for hit optimization studies and fragment growing might lead to new and potent MurA inhibitors.

Supplementary Materials: The following are available online at http://www.mdpi.com/1424-8247/13/11/362/s1, Table S1. Results of time-dependent $\mathrm{IC}_{50}$ measurements of $\mathbf{1 7 b}$; Figure S1. The MS/MS spectrum of $\mathbf{1 7 b}$ modified MurA enzyme peptide [amino acids 104-120] together with the annotation of the peaks; NMR, LC-MS and HRMS data of key compound 17a.

Author Contributions: Conceptualization, S.G., I.J.P.d.E. and G.M.K.; methodology, P.Á.-B., M.W.; investigation, D.J.H., A.K., L.P., M.H. and T.I.; writing—original draft preparation, P.Á.-B., D.J.H. and M.W., writing-review and editing, P.Á.-B., D.J.H., M.W., S.G., I.J.P.d.E. and G.M.K. All authors have read and agreed to the published version of the manuscript.

Funding: The research was funded by H2020 MSCA FragNet (project 675899), SNN 125496, OTKA PD124598 and 2018-2.1.11-TÉT-SI-2018-00005, and the Slovenian Research Agency core funding P1-0208.

Acknowledgments: We thank Hélène Barreteau for E. coli MurA plasmid and Hans Custers for HRMS measurements. The authors are grateful for Krisztina Németh and Pál Szabó for contributing to the analytical experiments.

Conflicts of Interest: The authors declare no conflict of interest. 


\section{References}

1. Bugg, T.D.H.; Walsh, C.T. Intracellular steps of bacterial cell wall peptidoglycan biosynthesis: Enzymology, antibiotics, and antibiotic resistance. Nat. Prod. Rep. 1992, 9, 199-215. [CrossRef] [PubMed]

2. Blake, K.L.; O’Neill, A.J.; Mengin-Lecreulx, D.; Henderson, P.J.F.; Bostock, J.M.; Dunsmore, C.J.; Simmons, K.J.; Fishwick, C.W.G.; Leeds, J.A.; Chopra, I. The nature of Staphylococcus aureus MurA and MurZ and approaches for detection of peptidoglycan biosynthesis inhibitors. Mol. Microbiol. 2009, 72, 335-343. [CrossRef] [PubMed]

3. Hrast, M.; Sosič, I.; Šink, R.; Gobec, S. Inhibitors of the peptidoglycan biosynthesis enzymes MurA-F. Bioorg. Chem. 2014, 55, 2-15. [CrossRef] [PubMed]

4. $\quad$ Chang, C.-M.; Chern, J.; Chen, M.-Y.; Huang, K.-F.; Chen, H.-H.; Yang, Y.-L.; Wu, S.-H. Avenaciolides: Potential MurA-Targeted Inhibitors against Peptidoglycan Biosynthesis in Methicillin-Resistant Staphylococcus aureus (MRSA). J. Am. Chem. Soc. 2015, 137, 267-275. [CrossRef]

5. Baum, E.Z.; Montenegro, D.A.; Licata, L.; Turchi, I.; Webb, G.C.; Foleno, B.D.; Bush, K. Identification and Characterization of New Inhibitors of the Escherichia coli MurA Enzyme. Antimicrob. Agents Chemother. 2001, 45, 3182-3188. [CrossRef] [PubMed]

6. Keeley, A.; Ábrányi-Balogh, P.; Hrast, M.; Imre, T.; Ilas, J.; Gobec, S.; Keserú, G.M. Heterocyclic electrophiles as new MurA inhibitors. Arch. Pharm. Chem. Life. Sci. 2018, 351, e1800184. [CrossRef]

7. Li, X.; Danishefsky, S.J. Cyclobutenone as a Highly Reactive Dienophile: Expanding Upon Diels-Alder Paradigms. J. Am. Chem. Soc. 2010, 132, 11004-11005. [CrossRef]

8. Paton, R.S.; Kim, S.; Ross, A.G.; Danishefsky, S.J.; Houk, K.N. Experimental Diels-Alder reactivities of cycloalkenones and cyclic dienes explained through transition-state distortion energies. Angew. Chem. Int. Ed. 2011, 50, 10366-10368. [CrossRef]

9. Ammann, A.A.; Rey, M.; Dreiding, A.S. Cyclobut-2-enones from Alkynes via Dichlorocyclobut-2-enones. Helv. Chim. Acta 1987, 70, 321-328. [CrossRef]

10. Huisgen, R.; Mayr, H. Reactions of cyclobutenones with nucleophilic reagents via vinylketen intermediates. J. Chem. Soc. Chem. Commun. 1976, 55-56. [CrossRef]

11. Danheiser, R.L.; Savariar, S. A general method for the reductive dechlorination of 4,4-dichlorocyclobutenones. Tetrahedron Lett. 1987, 28, 3299-3302. [CrossRef]

12. Lumbroso, A.; Catak, S.; Sulzer-Mossé, S.; De Mesmaeker, A. Efficient access to functionalized cyclobutanone derivatives using cyclobuteniminium salts as highly reactive Michael acceptors. Tetrahedron Lett. 2015, 56, 2397-2401. [CrossRef]

13. Graaf, C.; Vischer, H.F.; de Kloe, G.E.; Kooistra, A.J.; Nijmeijer, S.; Kuijer, M.; Verheij, M.H.P.; England, P.J.; van Muijlwijk-Koezen, J.E.; Leurs, R.; et al. Small and colorful stones make beautiful mosaics: Fragment-based chemogenomics. Drug Discov. Today 2013, 18, 323-330. [CrossRef]

14. Khatik, G.L.; Kumar, R.; Chakraborti, A.K. Catalyst-Free Conjugated Addition of Thiols to $\alpha$, $\beta$-Unsaturated Carbonyl Compounds in Water. Org. Lett. 2006, 8, 2433-2436. [CrossRef]

15. Ábrányi-Balogh, P.; Petri, L.; Imre, T.; Szijj, P.; Scarpino, A.; Hrast, M.; Mitrović, A.; Fonovič, U.P.; Németh, K.; Barreteau, H.; et al. A road map for prioritizing warheads for cysteine targeting covalent inhibitors. Eur. J. Med. Chem. 2018, 160, 94-107. [CrossRef]

16. Mihalovits, L.M.; Ferenczy, G.G.; Keserú, G.M. Catalytic Mechanism and Covalent Inhibition of UDPN-Acetylglucosamine Enolpyruvyl Transferase (MurA): Implications to the Design of Novel Antibacterials. J. Chem. Inf. Model. 2019, 59, 5161-5173. [CrossRef]

17. Wijtmans, M.; Denonne, F.; Célanire, S.; Gillard, M.; Hulscher, S.; Delaunoy, C.; Vanhoutvin, N.; Bakker, R.A.; Defays, S.; Gérard, J.; et al. Histamine H3receptor ligands with a 3-cyclobutoxy motif: A novel and versatile constraint of the classical 3-propoxy linker. Med. Chem. Commun. 2010, 1, 39-44. [CrossRef]

18. Brand, S.; de Candole, B.C.; Brown, J.A. Efficient Synthesis of 3-Aminocyclobut-2-en-1-ones: Squaramide Surrogates as Potent VLA-4 Antagonists. Org. Lett. 2003, 5, 2343-2346. [CrossRef]

19. Wasserman, H.H.; Piper, J.U.; Dehmlow, E.V. Cyclobutenone derivatives from ethoxyacetylene. J. Org. Chem. 1973, 38, 1451-1455. [CrossRef]

20. Hasek, R.H.; Gott, P.G.; Martin, J.C. Ketenes III. Cycloaddition of ketenes to acetylenic ethers. J. Org. Chem. 1964, 29, 2510-2513. [CrossRef] 
21. McCarney, C.C.; Ward, R.S.; Roberts, D.W. Reactions of ketenes with ethoxyalkynes: Synthesis of 2,2,4-trialkylcyclobutane-1,3-diones. Tetrahedron 1976, 32, 1189-1192. [CrossRef]

22. Philips, D.J.; Davenport, R.J.; Demaude, T.A.; Galleway, F.P.; Jones, M.W.; Knerr, L.; Perry, B.G.; Ratcliffe, A.J. Imidazopyriridines as VLA-4 integrin antagonists. Bioorg. Med. Chem. Lett. 2008, 18, 4146-4149. [CrossRef]

23. Ross, A.G.; Townsend, S.D.; Danishefsky, S.J. Halocycloalkenones as Diels-Alder Dienophiles. Applications to Generating Useful Structural Patterns. J. Org. Chem. 2013, 78, 204-210. [CrossRef] [PubMed]

24. Placebo Controlled Study in Subjects With Relapsing Forms of MS to Evaluate the Safety, Tolerability and Effects of CDP323. Available online: https://clinicaltrials.gov/ct2/show/NCT00484536 (accessed on 1 October 2020).

25. Chanteux, H.; Rosa, M.; Delatour, C.; Prakash, C.; Smith, S.; Nicolas, J.-M. In Vitro Hydrolysis and Transesterification of CDP323, an $\alpha 411 / \alpha 4 ß 7$ Integrin Antagonist Ester Prodrug. Drug Metab. Dispos. 2014, 42, 153-161. [CrossRef] [PubMed]

26. Schule, A.; Ates, C.; Palacio, M.; Stofferis, J.; Delatinne, J.-P.; Martin, B.; Lloyd, S. Monitoring and Control of Genotoxic Impurity Acetamide in the Synthesis of Zaurategrast Sulfate. Org. Proc. Res. Dev. 2010, 14, 1008-1014. [CrossRef]

27. Skarzynski, T.; Mistry, A.; Wonacott, A.; Hutchinson, S.E.; Kelly, V.A.; Duncan, K. Structure of UDP-N-acetylglucosamine enolpyruvyl transferase, an enzyme essential for the synthesis of bacterial peptidoglycan, complexed with substrate UDP-N-acetylglucosamine and the drug fosfomycin. Structure 1996, 4, 1465-1474. [CrossRef]

28. Rožman, K.; Lešnik, S.; Brus, B.; Hrast, M.; Sova, M.; Patin, D.; Barreteau, H.; Konc, J.; Janežič, D.; Gobec, S. Discovery of new MurA inhibitors using induced-fit simulation and docking. Bioorg. Med. Chem. Lett. 2017, 27, 944-949. [CrossRef] [PubMed]

Publisher's Note: MDPI stays neutral with regard to jurisdictional claims in published maps and institutional affiliations. 